\title{
The Christology of Ho Amnos tou Theou in The Contextualization of Yohannine theology: Domba and Adombain The History of Translation in Indonesia ${ }^{1}$
}

\author{
Andrew Scott Brake ${ }^{1)^{*}}$ \\ 1) The Christian and Missionary Alliance, Colorado Springs, CO 80920 \\ *) Correspondent author: albrakecma@gmail.com
}

Received: 24 July 2018/Revised: 31 March 2019 /Accepted: 16 April 2019

\begin{abstract}
How do we translate Ho Amnos tou Theou in a context where there is no concept of a sheep, lamb, or goat? How do we communicate the Christology of the Lamb of God? Is Christianity or Christology translatable? If so, has it been translated according to the intention of the writer of the gospel of John? Decisions in translation related to the concept of the Lamb of God have impacted the Christological understanding of the Gospel of John and the nature of Jesus over several decades of contextualization and translation in Indonesia. Indonesia is a nation of many people groups, many languages, and many cultures, some of which are very different from others. How the essence of the original Greek is translated demonstrates much about the missiological motives and principles of the translator as well as the Christological assumptions understood in the Gospel of John, particularly John 1:29. Should the concept of the Lamb, and all the Old Testament background assumed with that identity, be lost in translation simply because there is no such animal as a lamb in the receiving context? This author thinks not, based on a proper understanding of the Yohannine conception of that term, and his conception of the identity of Jesus as the Ho Amnos tou Theou. Therefore, translators must be wary of allowing the context dictate the translation to the detriment of the essential meaning while also seeking to properly contextualize so that the essential meaning is still communicated in a way that is understandable to the receiving culture. It is outside the scope of this paper to present a comprehensive investigation of all the languages that have been translation in Indonesia. Thus, this paper focuses on the Mee, Dani, Damal, Ngalik, and Moni languages of Papua.
\end{abstract}

Keywords: Christology, Ho Amnos tou Theou, theology, Adomba, Indonesia

${ }^{1}$ This article was presented as one of the forums of the Society of Biblical Literature Conference, July 2016, Seoul, Korea. 


\begin{abstract}
Abstrak
Bagaimana menerjemahkan Ho Amnos tou Theou dalam konteks di mana tidak ada konsep pengenalan binatang domba, anak domba, atau kambing? Bagaimana mengomunikasikan Kristologi Anak Domba Allah? Apakah Kekristenan atau Kristologi dapat diterjemahkan? Jika demikian, apakah itu telah diterjemahkan sesuai dengan maksud penulis Injil Yohanes? Keputusan dalam terjemahan yang berkaitan dengan konsep Anak Domba Allah telah berdampak pada pemahaman kristologis Injil Yohanes dan sifat Yesus selama beberapa dekade kontekstualisasi dan terjemahan di Indonesia. Indonesia adalah bangsa dari banyak kelompok masyarakat, bahasa, dan budaya. Beberapa di antaranya sangat berbeda dari yang lain. Bagaimana esensi dari bahasa Yunani asli diterjemahkan menunjukkan banyak tentang motif misiologis, dan prinsip-prinsip penerjemah serta asumsi kristologis yang dipahami dalam Injil Yohanes, khususnya Yohanes 1:29. Haruskah konsep Anak Domba, dan semua latar belakang Perjanjian Lama diasumsikan dengan identitas itu, hilang dalam terjemahan hanya karena tidak ada binatang seperti domba dalam konteks penerima? Penulis menjawab tidak, berdasarkan pada pemahaman yang tepat tentang konsepsi Yohanes dari istilah itu, dan konsepsinya tentang identitas Yesus sebagai Ho Amnos tou Theou. Oleh karena itu, para penerjemah harus berhati-hati dalam membiarkan konteks mendiktekan terjemahan sehingga merugikan makna esensial, dan juga berusaha mengontekstualisasikan dengan baik sehingga makna esensial masih dikomunikasikan dengan cara yang dapat dimengerti oleh budaya penerima. Di luar ruang lingkup tulisan ini untuk menyajikan investigasi komprehensif dari semua bahasa yang telah diterjemahkan di Indonesia. Dengan demikian, tulisan ini berfokus pada bahasa Mee, Dani, Damal, Ngalik, dan Moni di Papua.
\end{abstract}

Kata-kata Kunci: Kristologi, Ho Amnos tou Theou, teologi, Adomba, Indonesia.

\title{
Introduction
}

Robert Don Hughes asked about eighteen years ago, "Is the gospel tied to culture or outside of culture?"2 Along with Hughes we can wonder if the Bible is the one supreme authority above culture or should it submit to culture? How about our thoughts on theology? Should we begin with the Bible for our theological reflection or with culture, as we seek to develop a good, local theology? Are there aspects of the traditional culture, or the respondent culture, that are good in and of themselves so that the Bible may stand side by side with that culture? Are there bridges that may be used between the culture and the message of the Bible?

These are all issues of missiology and contextualization that are tied also to the issues of communication and translation. In his book, Communicating Christ Cross-Culturally, David Hesselgrave quotes Augustine, who said, "There are two things necessary to the treatment of Scripture: A

${ }^{2}$ See Robert Don Hughes, "Contextualization and the Missionary Endeavor," in Missiology, ed. John Mark Terry, Ebbie Smith, and Justice Anderson (Nashville, TN: Broadman and Holman, 1998), 328-329. 
way of discovering (modus inveniendi) those things which are to be understood, and a way of expressing to others (modus proferendi) what we have learned."' The difficulty is encountered with various forms of culture and varying degrees of differences between the culture of the communicator and the culture of the receiver.

A model of missionary communication, or contextualized communication, has three parts or "cultures" itself. These are the Biblical culture, ${ }^{4}$ the culture of the missionary, and the audience or respondent culture. The task of the communicator is to understand the Biblical culture as the unchangeable truth. The communicator who knows the truth is also an ambassador of that truth. The communicator, and his own culture, is not the source of truth. He is only a conduit of that truth, the truth of the higher and unchangeable Biblical culture. ${ }^{5}$

The second task of the missionary is to understand her own culture. This is the harder task, because the missionary must step outside of herself and evaluate and critique her culture from the perspective of the Bible, and from the perspective of an outside observer, as objectively as possible. The third task is that she must understand the respondent culture and then communicate what is derived from the Biblical culture to that culture. Hesselgrave also wrote that we, as people who want to communicate the gospel in a new culture, have to communicate the gospel to people who are foreign to that gospel (that is, people who have a worldview that is foreign to that gospel), understand the process of contextualization, and free that gospel from aspects of the communicator's own culture, the process of decontextualization. ${ }^{6}$

A significant part of that process of contextualization is translation, the translation of the oral message as well as the translation of the written word. Why is translation important? Lamin Sanneh wrote, "Language is not just the 'soul' of a people, as if it belongs to some sort of elite gnostic circle. Language is also the garment that gives shape, decorum, and vitality to conscious life, enabling us to appreciate the visible texture of life in its subtle, intricate variety and possibility." 'Sanneh speaks of Bible translation as "Christianity's response to claims of the exclusive superiority of one culture against another. To translate is not an option for the church." 8 Translation must be done, but must be done well. Translation of complex

${ }^{3}$ Quoted in David J. Hessegrave, Communicating Christ Cross-Culturally, 2nd ed (Grand Rapids, MI: Zondervan, 1991), 35.

4 "Biblical culture" does not refer to $1^{\text {st }}$ century Judaism or to the culture of ancient

Israel. Rather, the culture of a received truth in Scripture that does not change.

${ }^{5}$ Ibid., 108.

${ }^{6}$ See the fuller discussion of this in David J. Hesselgrave, Paradigms in Conflict: 10 Key Questions in Christian Mission Today (Grand Rapids, MI: Kregel, 2005), 243-277.

${ }^{7}$ Lamin Sanneh, Translating the Message: The Missionary Impact on Culture (Maryknoll, NY: Orbis, 1989; rev.2009), 238.

${ }^{8}$ Ibid, 242. 
concepts from the sending culture in ways that can be easily understood in the receptor culture is a monumental task for the translator.

This leads to the important question for this paper: what do you do when you seek to translate a concept that is foreign in the receptor culture? Sanneh gives several examples of complex concepts and the attempts to translate them in various contexts. One involves the translation of the phrase "feed my lambs" in the Eskimo culture. Seals cannot be used because they do not play the same role in Eskimo life as lambs did in the Hebrew culture. Seals are hunted animals and lambs were domesticated animals in ancient Hebrew culture.

This brings us to the specific question of the phrase "Lamb of God" in John 1:29 and the history of its translation in several Papuan languages in Indonesia. Before western culture made contact with the peoples of the interior of Papua, what was then called Irian Jaya, there was no concept of a lamb. They did not even know what one looked like. The primary animal in the Papuan culture then, and still today, is the pig. The pig is offered as a peace-keeping animal between feuding families. It is a sign of wealth, and an essential part of the Papuan diet. Can the local word for "pig" be used as a substitute for "Lamb" in John 1:29 in order to create a proper contextual translation or is this setting aside a primary and essential theological truth in the concept and background of lamb in the Old Testament? Sanneh wrote, "A necessary precondition for effective translation is surrender to the terms of the target culture, whatever exalted notions the translator may have about faithfulness and accuracy to the original forms." of God" going too far?

\section{Method}

The method for comparing, and contrast the decisions reaching in the translation of Lamb of God in John 1:29, the author interviewed Bible translators working in Papua as well as indigenous speakers of various translations considered. The author also researched secondary material (commentaries) on the Gospel of John as well as contextualization theory in translation.

\section{Discussion}

\section{Theological meaning of Lamb of God in John 1:29}

In John's gospel, we are immediately introduced to Jesus as the Lamb of God, as spoken by John the Baptist. He pointed at Jesus and declared, "Look, the Lamb of God, who takes away the sins of the world." There have been a number of possibilities presented for the precise meaning of the 
phrase "Lamb of God," from John the Baptist's point of view and from the view of John ${ }^{10}$, the author of the gospel.

D. A. Carson, in his discussion of John 1:29 and the "Lamb of God," lists ten possibilities for the meaning of the Lamb of God. This include the gentle Lamb of Jeremiah 11:19, the lamb of the daily sacrifice, the scapegoat of Leviticus 16 (though this was a goat, not a lamb), the lamb of the Abraham/Isaac story in Genesis 22, the Guilt offering of Leviticus 14 and Numbers 6, the servant of the Lord in Isaiah 53, the apocalyptic lamb of Revelation 7:17 and 17:14, the Passover lamb of the Exodus Passover, the lamb of Isaiah 53:7 who is led to the slaughter, or a phrase that is grammatically parallel with Son of God in John 1:34. ${ }^{\text {ll }}$ Which of these is closer to John's intention?

In John's theological movement of his gospel, the whole story moves toward the glory of the cross, the "hour" to which Jesus often referred (for example see 2:4 and 7:6). When Jesus is introduced for the first time in the gospel, then, the language of sacrifice is present in the phrase "lamb of God." ${ }^{12}$ Kostenberger sees the importance of this unfolding theological significance. "By the time John has told his story, his reader will know that Jesus took away the sin of the world by his atoning sacrifice on the cross and that he truly is the messianic king of Israel."13

According to F. F. Bruce, "No one usage accounts for the complete background, and even if the complete background could be discovered it would not entirely account for the New Testament usage, which has a new and creative element in it." 14 Instructive for this discussion is John's concept of the Lamb of God in Revelation. In this apocalyptic vision, the Lamb of God has authority, sovereignty and power. He is the center of heaven's praise, and is victoriously seated at the right hand of God. In fact, in Rev.3:21 Jesus promised those who remain faithful in Philadelphia that they would sit with him on his throne, just as he overcame and "sat down

${ }^{10}$ To avoid confusion, the author will simply refer to the author of the gospel of John as John, as traditionally understood, knowing also the complex, recent history of scholarship that casts doubt on this conclusion. The author believes that John is the author of the gospel so named.

${ }^{11}$ D. A. Carson, The Gospel According to John (Grand Rapids, MI: Eerdmans, 1991), 149. See also similar lists in Andreas J. Kostenberger, A Theology of John's Gospel and Letters (Grand Rapids, MI: Zondervan, 2009), 414-415; Leon Morris, The Gospel According to John (NICNT) (Grand Rapids, MI: Eerdmans, 1971), 143-149.

${ }^{12}$ See Murray Rae, "The Testimony of Works in the Christology of John's Gospel," in Richard Bauckham and Carl Mosser, eds, The Gospel of John and Christian Theology (Grand Rapids, MI: Eerdmans, 2008), 303.

${ }^{13}$ Kostenberger, 318. Also see Andreas J. Kostenberger, John (BECNT) (Grand Rapids, MI: Baker, 2004), 66. "The notion of sacrifice does not appear for the first time here in this Gospel; it is already hinted at in the prologue's portrayal of Jesus as God's 'one-of-a-kind Son' a la Isaac."

${ }^{14}$ F. F. Bruce, The Gospel of John: Introduction, Exposition and Notes (Grand Rapids, MI: Eerdmans, 1983), 52. 
with my Father on his throne." The throne of God is a position of authority and power.

But that authority and power was given to the Lamb because he was slain. The new song sung to the Lamb who was slain in Revelation 5:9 is "You are worthy to take the scroll and to open its seals, because you were slain, and with your blood you purchased men for God from every tribe and language and people and nation." And in Revelation 13:8 Jesus is referred to as "the Lamb that was slain from the creation of the world." From the Evangelist's point of view, then, the Lamb of God carries apocalyptic weight as well as sacrificial meaning. The Lamb of God reigns on the throne because he was slain. The Lamb of God that takes away the sins of the world does so triumphantly through the pathway of the cross.

Carson leans toward the apocalyptic meaning but sees also the possibility that John read into the Baptist's words a sense of expiation. ${ }^{15}$ And Morris sees John's intention as both meanings of the Lamb of God but concludes, "The fact is that "God's Lamb" is too indefinite an expression for us to confine the meaning to any particular lamb, at least to any which has so far been suggested... The majority of the suggestions that have been made have this in common that in one way or another they understand the words to refer to the offering of Christ as a sacrifice availing to put away the world's sin. The conspicuous exception is that which sees the Lamb as an eschatological figure." ${ }^{16}$ Perhaps one ought to conclude with Hendricksen's conclusion several decades ago, "Why is it necessary to make a choice? Were not all of these types fulfilled in Christ, and was he not the antitype to whom they all pointed?"17 Whale concludes the same. The "Lamb of God" may be based on Isaiah 53:6,7, but that does not mean that passage only bears the understanding of the phrase. ${ }^{18}$

So, what was John's intended meaning? Is this an example of John the Baptist speaking more than he knew or understood? In another part of the gospel (11:50) John has Caiaphas speaking more than he knew when he prophesied the sacrifice of one man for the whole nation. It is possible that John the Baptist was doing the same. In the mind of the Baptist Jesus was the apocalyptic Lamb, the warrior messianic lamb that was anticipated in texts such as 1 Enoch 90:9-12 and the Testament of Joseph 19:8. ${ }^{19}$ But to

${ }^{15}$ Carson, 150.

${ }^{16}$ Leon Morris, Apostolic Preaching of the Cross (Kindle Edition: Eerdmans, 1965), Loc.2303-2307.

17 William Hendricksen, Exposition of the Gospel According to John (Grand Rapids, MI: Baker, 1961), 98.

${ }^{18}$ Peter Whale, "The Lamb of John: Some Myths about the Vocabulary of the Johannine Literature," Journal of Biblical Literature 106, No.2 (June, 1987): 291. Also, Carl J. Laney, Moody Gospel Commentary: John (Chicago: Moody Press, 1992), 52, concludes that it is probably that the Lamb of God descriptions focuses on more than one particular Old Testament metaphor about God's sacrificial provision.

${ }^{19}$ Carson, 150. 
that concept of Jesus as apocalyptic warrior-Lamb, John added the theological imagery of sacrifice. According to Christopher Skinner, "The 'Lamb of God' can be regarded as both an utterance of John the Baptist as well as a powerful theological affirmation by the Evangelist." From the viewpoint of the Baptist, Jesus is the Apocalyptic, conquering Messiah of the inter-testamental period. From the viewpoint of the Evangelist, Jesus is the Passover Lamb who takes away the sins of the world. ${ }^{20}$ In this sense John is contextualizing the phrase as well, fitting it with Isaiah 53 or Genesis 22, or any other of the sacrificial concepts of the Old Testament.

Whatever meaning is preferred, what would have been inconceivable in the Jewish mind is to substitute a pig for the concept of a lamb. A Passover pig? A pig substitute for Isaac? A victorious pig of God on the throne? That becomes the essential question of contextual translation in Papua. Can the theological significance of an unblemished lamb in the Old Testament be represented by the concept of a pig, an unclean animal in the minds of Biblical authors, albeit an animal of sacrifice in Papua? It is this question that has challenged translators in the Papuan context over the last fifty years.

\section{Survey of decisions in translation in Papua, Indonesia}

Below are five languages in Papua that have been translated in the past half century. Listed first is the Greek, the English (NIV), then the Indonesian translation from 2007, followed by five languages in Papua: Ngalik, Damal, Dani, Moni, and Mee. ${ }^{21}$ Underlined in each translation is the phrase "Lamb of God."

\section{Greek}

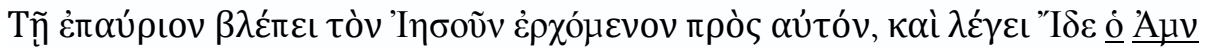

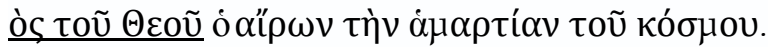

\section{English}

The next day John saw Jesus coming toward him and said, "Look, the Lamb of

God, who takes away the sins of the world. ${ }^{22}$ Indonesian

Pada keesokan harinya Yohanes melihat Yesus datang kepadanya dan ia berkata: "Lihatlah Anak domba Allah, yang menghapus dosa dunia." 23

${ }^{20}$ Christopher W. Skinner, "Another look at the "lamb of God." Bibliotheca Sacra. Vol. 161, No.164 (Jan-March, 2004), 104. See also David W. Wead, "The Johannine double meaning," Restoration Quarterly. Vol.13, No.2 (1970), 106.120; and Kostenberger, John, 66. According to Kostenberger "John the Baptist here speaks better than he knows."

${ }^{21}$ There are more than 250 known languages in Papua. For the sake of this article and the author's sanity, only five are considered here.

22 NIV Translation, 1984.

${ }^{23}$ New Translation published by the LAI (Jakarta: Lembaga Alkitab Indonesian, 2007). The LAI is the Indonesia version of the American Bible Society. 
Ngalik

Wene asogo egesarik, nogo oluk, hubet o'gwe re, at Yesus Yohanes e'bek wagokhwe il yetholuk e, wene disogo mo'gulentesi, “Allah uam domba a'ge nis aphwami 'gwiangma wiak togu lege a'ge no'gorlogo ukpouwa ag'ge ano waga etle hinil yethemit $0 .{ }^{24}$

The Ngalik word for pig (uam) proceeds the Indonesian word for sheep (domba). The literal translation would be pig-sheep. ${ }^{25}$

Dani

Wene itithogon isukhasik nen, noge iluk, hubuluke, at Yesus Yohanes oba wagunem ileken lakhalok nen, wene men yogeisasikhe, "Allah adomba eak meke nit akhuni agat oba yoma weak hagakhorek meke korogo thogotdisagein meke etnogo waga ili hinileken lakhani o". ${ }^{26}$

The literal translation of this is: "God's baby sheep that us people on earth that do bad, he that takes away the bad we do is coming let your eyes see. ${ }^{27}$ The decision was made not only to introduce the foreign word from Indonesian, domba, but also to add a Dani language marker on the front, aThe translator also chose to introduce the foreign word from Indonesian for God, Allah. It is evident that Ngalik and Dani are related languages from the similarities in the translations.

\section{Damal/Amungme}

Na haen togan jomut-o, Jetut-o Joanet namala ara motet-e. Moma noneagan, Joanet-a habin-o: "Me ara nonet-te. Ungkangam Me nandompa boe nebel-ak woram nak-o. Ki me kop-an koak de-yongam kamo-ak jogon pan emelek me-a di-iy-e." ${ }^{28}$

The Damal language in Papua comes from the interior highlands of Papua - 12-15 valleys clustered around the highest peaks of the Carstenz Mountains. The mountain peak, Puncak Jaya, is the highest point between the Himalayas in Nepal and the Andes in South America. The literal translation reads, "Having said that and spent the night, Jesus came to where John was. Having seen him coming, John said, 'Look at that man. I

24 This translation was provided by Buzz Maxey, an international worker for relief and development in Wamena, Papua. Buzz grew up in Papua. His mother, Shirley Maxey, worked on the Ngalik translation. This translation is currently being edited by Buzz and his wife, Myrna.

${ }^{25}$ Email from Buzz Maxey to author, March 15, 2016.

${ }^{26}$ Ibid.

27 According to Buzz Maxey, this is the Dani literal translation word-for-word that his mother, Shirley Maxey translated. Email to author, March 15, 2016.

${ }^{28}$ Translated by Dr. John Ellenberger, a long time missioanry and translator among the Damal people. The present name for the Damal is Amungme, a name they took for themselves. The Damal currently have a published New Testament, and about 500 verses of the Old Testament. John and Helen Ellenberger are working to complete the Old Testament. 
see exactly that he is the Creator's sheep-pig. He is the one who will completely wipe out all the evil deeds of those who live in the place of real people."”

The Damal spirit world has no good spirits and no supreme being. Rather Damal people seek to appease the evil beings and manipulate the malevolence for their own benefit. The term Ungkangam Me, "One who made in the distant past," is borrowed from a neighboring Highland group, the Mee (see below), who have a concept of creation and creator, their term being Ukatama. The first missionaries into the Damal area were accompanied by a Mee believing head man, who shared with many Damals about "Ukatame." Because the term is similar, however, the Damal people heard "Ungkangam Me," and the term stuck.

The only domesticated and edible animal the Damal people had was the pig, so they had no knowledge or picture of a sheep. This term is adapted, as in the examples above, from the Indonesian word for sheep, domba. The word, boe, the Damal word for pig, was added after the word for sheep to indicate that it was a domesticated, edible animal. This Damal word can mean both the animal, "pig," and also has the meaning of "cattle," or a "domesticated, edible animal." Context differentiates which is meant.

According to Ellenberger, the understanding of "sacrificial animal" is clearly here, but most translations do not make this explicit. "This faces the old question of how much understood meaning is the role of the translator and how much is the role of the preacher. Perhaps for Damals we should have added, "Ungkangam Me nangkai tagagan, kogom jingkan abulingam boe-a di-iy-e," which means, "The animal that is to be killed and its blood dumped out before the Creator." ${ }^{29}$

Moni

Uma maga wadagi naga-go Zesusi-ge ogomba mindi togo Zohanes-ge inigata ogoti hindia-go, "Me ka inie. Mene-ge biga dega tawa endauagi uiti domba wogo pa wapi-wapi dia degega nagama data, Me ka-ge ko emo ka emo tuia mene ondoma-ge biga dega agapa maga punu-o, ta Aiga Sonowi-ge Ogo oga mebataga. Di dogo-go, Ogo-go Aigi Sonowi Domba Pa-ge dia. ${ }^{30}$

The Moni are a people group who live in the Baliem Valley in central Papua. This translation is currently in revision and Henok Bagau, the head of the theological school in Timika, Papua, and an active participant in the translation revision, is from the Moni people. The revision process has been in conjunction with the Lembaga Alkitab Indonesia, the Indonesian version of the American Bible Society. Henok Bagau is a member of the LAI.

The literal translation would be something like, "Look at that person. He is just like a person who kills/sacrifices his sheep pig to take away their

${ }^{29}$ Email to author, March 10, 2016.

${ }^{30}$ This translation was done by William Cutts (Jakarta: Lembaga Alkitab Indonesia, 1988). 
sin, so also He is the Lamb of God who takes away he sins of humanity who live in all the world." According to Bagau, the word for lamb/sheep in Moni is Domba Wogo, or sheep pig. The names for all the different kinds of domestic animals also includes the marker for pig, or wogo. For example, a chicken is bega wogo (chicken pig), a rabbit is So wogo (rabbit pig), a goat is Kambini wogo (goat pig), and a cow is sapi wogo (cow pig). In the all the texts of the Bible, all the different kinds of animals can referred to in the same way. But, the phrase, "The Lamb of God," in John 1:29 cannot become "The Lamb pig of God," because this is a referential term for Jesus, and it is not proper to call Jesus the "Lamb pig of God." 31

So, there are two attempts in the Moni translation to communication the concept of a lamb. The first is the more general expression, as if we were saying, "That is a lamb/pig type of animal, that is usually sacrificed for the sins of others." But when referring to Jesus, the Moni do not feel right in calling Jesus a "lamb-pig." They use the more general Indonesian expression in their translation even though it does not fit the normal form of animal reference.

Mee

Aweetaa naago kiyake Yesus okaapa meete edoyake keti teete mana, "Edodowei, Ugatameya Domba Yoka kidi. Makiida maki utoma ka peudo wado yamotigota me kidi." 32

Aweetaa naago kiyake ko Yohanes kidaa Yesus kidi okaapa meete kodo edooyake okaiya godata mana ko, "Edoodowei! Ugatameya Domba Yoka kidi, makiida maki utoma ka peudo kodo wado yomotigoune mee kidi!"33

This translation was initiated by Marion Doble, an international worker assigned to Irian Jaya from 1947 to 1990. She spent most of her career in what was called the Wissell Lakes Region. The language was called the Ekari language at the time but is now known as the Mee. Miss Doble was an "honorary translation advisor for the United Bible Societies and participated in workshops for training translators, expatriates, and nationals." ${ }^{34}$

Before the Mee translation was completed and at the time of it, there was no concept of a lamb in the Paniai region ${ }^{35}$ (western Papua). Miss Doble used pictures to explain what they were. The decision to use domba instead of a word for pig, ikena, was based on the character of the pig. For

\footnotetext{
${ }^{31}$ Email from Henok Bagau to author, March 23, 2016.

${ }^{32}$ This translation is from the older Mee Bible translated in 1977.

33 This is the newer Mee translation: Ayii Mana: Dogaka Togiyawita ma Iyaka Togiyawita ma (Jakarta: Lembaga Alkitab Indonesia, 2013), 267.

34"Retired Missionary to Irian Jaya," https://www.cmalliance.org/news/2005/14/14/retired-missionary-to-irian-jaya-

${ }^{35}$ At the time of Miss Doble, this area was known as the Wissell Lakes region, named after the man who found that there were settlements around these lakes before the start of the World War II.
} 
example, if a child was not behaving properly the people would say, "he is acting like a little pig," because little pigs had no self-control. Later, lambs were brought into the area by the Indonesian government. The people then understood the character of the lamb for themselves. ${ }^{36}$

By the time Yohanes Gobay, the author's source for this information, was a boy, he knew what lambs were. There was an older woman in his village that owned a lamb. If Yohanes called the lamb, it did not move. But if the woman called her lamb, it would immediately lift up its head in response to the sound of its master's voice. ${ }^{37}$

Table 1. Language and translation of the Lamb

\begin{tabular}{|c|c|}
\hline Language & Translation \\
\hline Greek & 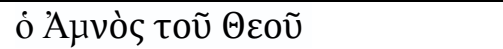 \\
\hline English & Lamb of God \\
\hline Indonesian & Anak Domba Allah \\
\hline Ngalik & Allah uam Domba \\
\hline Dani & Allah adomba \\
\hline Damal & Ungkangam Me nandompa boe \\
\hline \multirow[t]{2}{*}{ Moni } & Uiti domba wogo 38 \\
\hline & Aigi Sonowi Domba Pa-ge ${ }^{39}$ \\
\hline Mee & Ugatameya Domba Yoka kidi \\
\hline
\end{tabular}

\section{Conclusion}

A common debate in missiological circles today is the necessity of form and its influence/or lack of on the essential meaning of a concept. For example, does the form of prayer for Muslims in a mosque carry meaning? The answer to this question will dictate the levels of contextualization. This can be applied to the area of translation as well. According to Hesselgrave, "Missionary contextualization that is authentically and effectively Christian and evangelical does not begin with knowledge of linguistics, communications theory, and cultural anthropology. It begins with a commitment to an inerrant and authoritative Word of God in the autographs of Old Testament and New Testament Scripture." 40 The extent to which one agrees with Hesselgrave may determine how far one is willing to compromise in translations decisions such as the one we have been discussing.

${ }^{36}$ Author interview with Yohanes Gobay, March 9, 2016. Yohanes Gobay is a pastor of the Gospel Tabernacle (GKII) Church in Timika, Papua, and advisor to the Leadership Board of the GKII. He grew up in the Paniai area and is part of the Mee people.

${ }^{37}$ Ibid.

${ }^{38}$ The first, and more general use of the term for lamb.

${ }^{39}$ The second, and more specific reference to Jesus, that does not use the word for pig, wogo.

${ }^{40}$ Hesselgrave, Paradigms, 274. 
According to Richard Kroneman, an international Translation Coordinator for SIL in Papua, and translator of the Bible into the Una language of Papua, "In light of the clear distinction between 'sheep' and 'pigs' (unclean) in the Bible, it is important that this distinction is clearly articulated in Bible translations." 41 There is far too much theological weight in the concept of "Lamb of God" for it to be either lost in translation or "explained" with the addition of a word for pig. Especially in light of the negative connotations of the unclean pig in the Old and New Testament. Although Jesus declared all foods clean (see Mark 7:19), including pork, it is too much of a theological leap to substitute pig for lamb or a combination of the two for the phrase "Lamb of God" in John 1:29. ${ }^{42}$

An example of a translation possibility that is of less weight in the matters of theological contextualization is Jesus' statement in Matthew 10:16, "I send you out as sheep in the midst of wolves." An appropriate contextual rendering that does not alter the core theological importance of the text is "I send you out as young pigs among wild dogs." ${ }^{3}$ But to substitute "young pigs" for "sheep" in this context is far different than substituting "sheep-pig" or "pig" when referring to the person of Jesus and all the theological weight associated with the "Lamb of God."

In cultures that are newly literate, and indeed in many cultures that are fully literate, the average learner understands concepts, concrete and abstract, best when communicated visually. This was possibly the reason for Marion Doble's success in the 1950s in the Wissell Lakes. She used pictures to explain the concept of the lamb. Those visual aids implanted a seed of understanding in the minds of the hearers that later helped them more deeply understand the concept of the Lamb of God in later generations, especially when they were able to see a lamb for themselves. Such was the response of the Mee people (an "Aha" moment) who understood the context of the "lamb of God" translation in their Bible when they were given the opportunity to see an actual lamb many years after the completion of the translation. Orality, visual aids, and discipleship must accompany translation. Translations cannot be completed in a vacuum,

${ }^{41}$ Email to the author, March 28, 2016. Richard Kroneman did his dissertation at Vrije Univeristeit Amsterdam, entitled The LORD is my Shepherd. An Exploration into the Theory and Practice of Translating Biblical Metaphor, 2004. "Lamb of God" from John 1:29 in the Una translation is "domba mi," or "son of sheep." There is no introduction of the concept of pig (bisam) in this translation.

${ }^{42}$ It is interesting that the two translations of the five above that do not use the word for pig in reference to Jesus are defended and explained by Papuan nationals. A. Scott Moreau's advice about listening to the voice of the locals is instructive here. See A. Scott Moreau, Contextualization in World Missions (Grand Rapids, MI: Kregel, 2012), 111-114. Marks of good contextual process is that is incorporates diverse voices in the process living voices of the community itself and historical voices of the theological history of the church.

${ }^{43}$ Kroneman, 500. 
with hundreds of translated Bibles piled up in a shed in the village with no one reading them. Translation must be part of the process of contextualization and discipleship, with a faithful adherence to the deeper theological concepts that cannot be compromised. This is true contextualization in translation - when understanding occurs in the soul of the hearer without the loss of the original meaning.

\section{Bibliography}

Bruce, F. F. The Gospel of John: Introduction, Exposition and Notes. Grand Rapids, MI: Eerdmans. 1983.

Carson, D. A. The Gospel According to John. Grand Rapids, MI: Eerdmans. 1991. Greene, G. Roger. "God's Lamb: Divine Provision for Sin." Perspectives in Religious Studies 37, No.2 (Sum, 2010): 147-164.

Hendricksen, William. Exposition of the Gospel According to John. Grand Rapids, MI: Baker. 1961.

Hesselgrave, David J. Communicating Christ Cross-Culturally, $2^{\text {nd }}$ ed. Grand Rapids, MI: Zondervan. 1991. . Paradigms in Conflict: 10 Key Questions in Christian Mission Today.

Grand Rapids, MI: Kregel. 2005.

Hughes, Robert Don. "Contextualization and the Missionary Endeavor," in John Mark Terry, Eddie Smith, and Justice Anderson, eds. Missiology. Nashville, TN: Broadman and Holman. 1998.

Kostenberger, Andreas J. John (Baker Exegetical Commentary on the New Testament). Grand Rapids, MI: Baker. 2004.

Zondervan. 2009.
Kroneman, Richard. The LORD is My Shepherd. An Exploration into the Theory and A Theology of John's Gospel and Letters. Grand Rapids, MI: Practice of Translating Biblical Metaphor. Vrije Universisteit Amsterdam dissertation. 2004.

Laney, J. Carl. Moody Gospel Commentary: John. Chicago: Moody Press. 1992. Marshall, I. Howard. "Lamb of God," Dictionary of Jesus and the Gospels.

Downer's Grove, IL: IVP. 1992.

Moreau, A. Scott. Contextualization in World Missions. Grand Rapids, MI: Kregel. 2012.

Morris, Leon. Apostolic Preaching of the Cross. Eerdmans: Kindle Edition. 1965.

Rae, Murry. "The Testimony of Works in the Christology of John's Gospel," in Richard Bauckham and Carl Mosser, eds. The Gospel of John and Christian Theology. Grand Rapids, MI: Eerdmans. 2008.

Sandy, O. Brent. "John the Baptist's 'Lamb of God" affirmation in its canonical and apocalyptic milieu." JETS 34, No.4 (December, 1991): 447-459. 
Sanneh, Lamin. Translating the Message: The Missionary Impact on Culture. Maryknoll, NY: Orbis. 1989; rev.2009.

Skinner, Christopher W. "Another Look at the "Lamb of God." Bibliotheca Sacra 161, No. 164 (Jan-March, 2004): 89-104.

Stein, Robert H. Jesus the Messiah: A Survey of the Life of Christ. Downer's Grove, IL: IVP. 1996.

Wead, David W. "The Johannine double meaning." Restoration Quarterly 13, No. 2 (1970): 106-120.

Whale, Peter. "The Lamb of John: Some Myths about the Vocabulary of the Johannine Literature." Journal of Biblical Literature 106, No.2 (June, 1987): 289-295. 